\title{
RADIOCARBON DATING OF RECENT INTERTIDAL MICROBIAL MATS ON ATOLL RIMS
}

\author{
Jean Trichet $^{1}$ • Christine Hatté2,3 ${ }^{2}$ Michel Fontugne ${ }^{2}$ \\ ABSTRACT. Microbial mats (kopara in Polynesian) that develop in shallow brackish to hypersaline ponds on the rims of \\ atolls were investigated for their accumulation process and rate. Two sequences of $\sim 30$-cm-deep kopara, composed of 7 and \\ 5 layers distinguished by their colors and sedimentological facies were collected in 1996 from the Tetiaroa atoll, French \\ Polynesia. The combination of radiocarbon activity measurements on both organic and carbonate constituents, reservoir \\ effect estimation, and comparison with the Southern Hemisphere atmospheric bomb-peak ${ }^{14} \mathrm{C}$ record allowed us to establish \\ a fine chronology of the layer successions documenting the mode of formation, erosion, and restoration of these microbial mat \\ deposits.
}

\section{INTRODUCTION}

Intertropical intertidal microbialites have been described on atoll rims in the Pacific Ocean (Défarge et al. 1994b, 1996; Mao Che et al. 2001; Arp et al. 2012). They are similar to other microbialites in salty marshes and hypersaline open surfaces (Abed et al. 2007; Franks and Stolz 2009) and to the soft part of lithified stromatolitic structures (Spadaflora et al. 2010; Reid et al. 2011). Intertidal microbialites, growing in superficial ponds on reef rims, differ from intralagoonal (Sprachta et al. 2001; Abed et al. 2007) and submarine microbialites (Camoin et al. 1999, 2006; Heindel et al. 2010; Westphal et al. 2010) in several respects: their habitat - they lie in shallow (depth $<2 \mathrm{~m}$ ) ponds or pools; the variability of their chemical environment; their waters vary from freshwater (GarciaPichel et al. 2004; Gischler et al. 2008) to hypersaline (Défarge et al. 1994a,b; Trichet et al. 2001; Reid et al. 2003; Arp et al. 2012); and the strong insolation to which they are exposed. These microbial mats are composed of diverse phototrophic and heterotrophic microbial communities. They typically exhibit a multilayered structure resulting from periodic growth (from diel [Decho et al. 2005] to more variable rhythms [Reid et al. 2003, 2011]). A typical succession is expressed as follows from the top to the bottom: 1 ) a green top layer, rich in photosynthetic cyanobacteria, producing oxygen during the day and creating a temperate oxygenic environment; 2) a thin purple layer whose color is due to the presence of pigments contained in sulfur-oxidizing bacteria; 3 ) a thick (a few cm) red anoxic layer whose color can probably be attributed to the presence of red carotenoid pigments liberated during the decay of oxygenic and anoxygenic phototrophic bacteria having grown in the upper green and purple layers (Mao Che et al. 2001; Trichet et al. 2001); 4) a more or less thick bottom layer, whose color varies from orange to pale pink presumably depending on the increasing decomposition of the red pigments coming from the overlying layer and the precipitation of authigenic white high-Mg calcite minerals (Défarge et al. 1994b).

In the recent past, this natural resource was consumed when food was scarce; it seems to be still used for feeding in some archipelagos of the central and northwest Pacific Ocean. It was also employed as a healing plaster. Because of some of its properties, especially the nutritional and medical ones, kopara may be of interest in various fields, e.g. medical and paramedical applications (antibacterial and healing properties), the food industry (where carotenoids are used as dying agents), and pedology (stabilizers).

1391 rue de Lorette, F-45160 Olivet, France.

${ }^{2}$ Laboratoire des Sciences du Climat et de l'Environnement (UMR 8212 CEA/CNRS/UVSQ), Domaine du CNRS, F-91198 Gif-sur-Yvette Cedex, France.

${ }^{3}$ Corresponding author. Email: Christine.Hatte@lsce.ipsl.fr.

(c) 2013 by the Arizona Board of Regents on behalf of the University of Arizona Proceedings of the 21st International Radiocarbon Conference edited by A J T Jull \& C Hatté RADIOCARBON, Vol 55, Nr 2-3, 2013, p 1603-1616 


\section{$J$ Trichet et al.}

Two sequences composed of 7 and 5 layers distinguished by their colors and sedimentological facies were collected in 1996 from the Tetiaroa atoll. This study will focus on the following 3 points:

1. What is the accumulation rate of the kopara deposit? How renewable is the kopara resource?

2. What is the age of the authigenic carbonate minerals in each layer with regard to that of the surrounding organic matter? Does this result confirm their authigenic origin as in the theory previously proposed by Défarge et al. (1994a,b)?

3. What is responsible for their preservation and for their erosion?

Thus, a radiocarbon analysis of the mineral and organic phases of these layers is presented here.

\section{MATERIAL AND METHODS}

\section{Sampling Sites}

The studied samples were collected respectively in a water pond (referred to as TI) and on the bank of the pond (referred to as TII) on the atoll rim of Tetiaroa atoll $\left(17^{\circ} 00^{\prime} \mathrm{S}, 149^{\circ} 34^{\prime} \mathrm{W}\right.$ ) (Figure 1a-e), located $42 \mathrm{~km}$ north of Tahiti, in French Polynesia (Figure 1b). The samples were collected in January 1996 by hand-coring sediments with a transparent plastic, 12-cm-wide tube, down to $36 \mathrm{~cm}$ in TI (Figure $1 \mathrm{f}$ and 2) and to $33 \mathrm{~cm}$ in TII (Figure 3), overlain by 2 and $0 \mathrm{~cm}$ depth, respectively. Samples were gathered in $4{ }^{\circ} \mathrm{C}$ refrigerated boxes, in the dark, and maintained in vertical position in order to prevent any lateral movement and mixing in the sediment within the tubes. Transport from Tetiaroa atoll to France lasted 3 days. They were then sectioned, according to sedimentological layering, into 12 subsamples in the TI column and into 5 subsamples in the TII (Figure 2). All the subsamples were freeze-dried.

\section{Sedimentological Description of the Cores}

The sampled microbialites of Tetiaroa atoll are multilayered deposits, whose total thickness varies from $1 \mathrm{~cm}$ to several tens of $\mathrm{cm}$, generally $<40 \mathrm{~cm}$ (Figures 2 and 3). As can be observed in the field, the sedimentary column displayed 7 multicolored layers in core TI, and 5 in core TII, among which red layers were the most easily visible to the naked eye (samples TI-2, TI-5, TI-7 in TI pond and TII4 in pond TII). From the top to the bottom (Figure 2), the TI section evidences: a green top layer (TI1); then a very thin purple layer (not shown in Figure 2); followed by a red, 1.5-cm-thick layer (TI2) that overlies 2 pale orange to yellowish layers (TI-3 and TI-4); a second red layer (TI-5) then follows and overlies a sandy yellowish layer that contains reworked material from a subsequent red layer (TI-7) at its base.

From the top to the bottom (Figure 3), the TII section comprises: a 4-cm-thick yellowish recent kopara layer over a 5-cm- thick higher-plant residues layer (TII-2) that caps a 2-cm-thick grayish layer (TII-3) and a 5-cm reddish old kopara layer (TII-4) that overlies yellowish old kopara layers (TII-5 and TII-6). Modern higher-plant (reed) growths on this succession and roots go $30 \mathrm{~cm}$ deep.

The 2 sections show the presence of allochthonous detrital material inserted between organic layers of microbial origin, a sandy layer (TI-6) in core TI, and a higher-plant debris layer (TII-2) in core TII.

\section{Material and Methods Used for Dating}

Sedimentary material was treated according to its facies type and to its natural constituents. We thus extracted 2 types of samples: red and yellowish organic matter and carbonate from yellowish layers. 

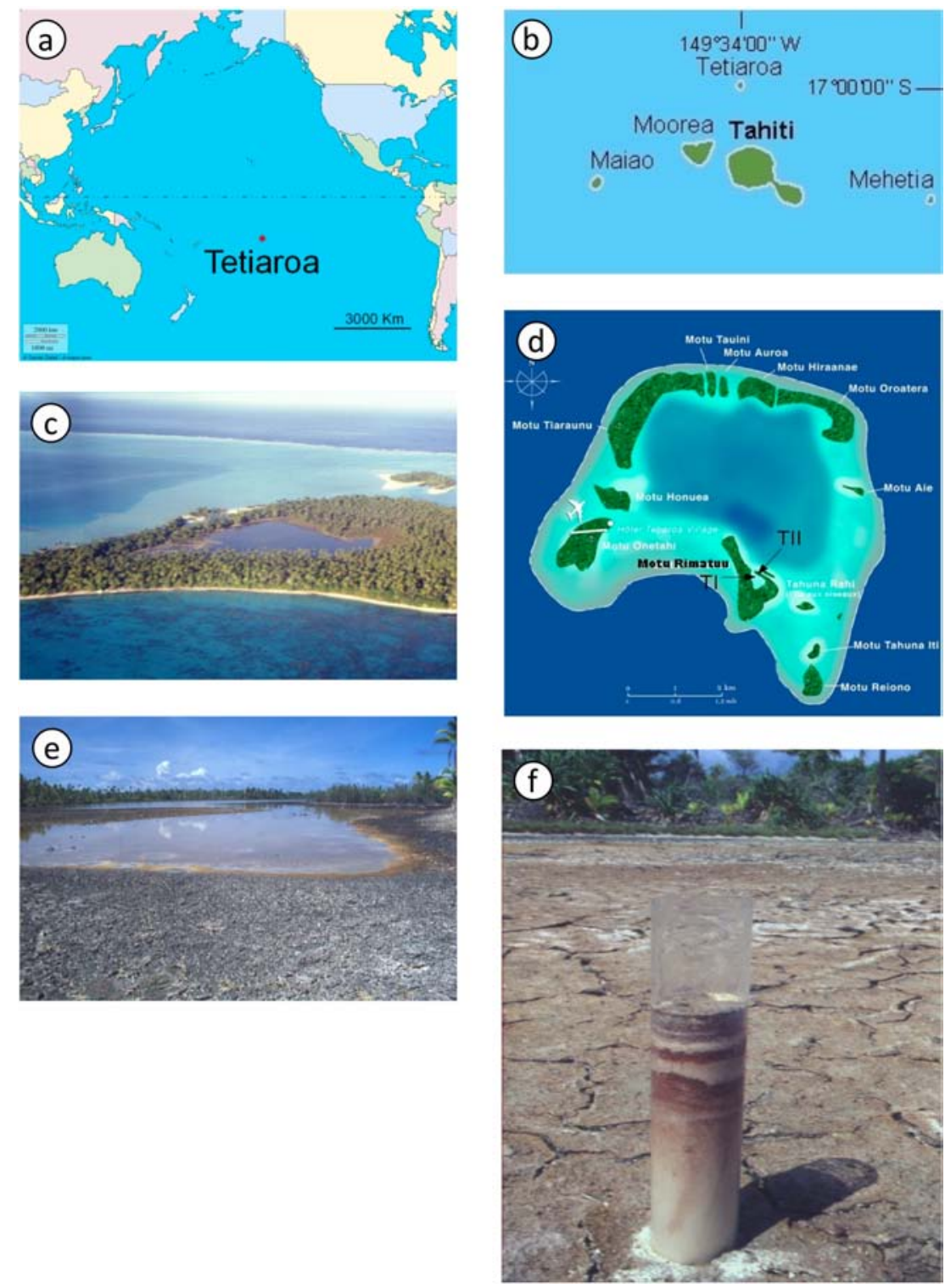

Figure 1 Location of samples: (a) Tetiaroa atoll in the Pacific Ocean; (b) Tetiaroa atoll in the Society Islands; (c) Aerial view of the prospected pond within the Motu Rimatuu; (d) Map of Tetiaroa atoll showing the location of cores TI and TII; (e) Close view of the prospected pond; (f) Sedimentary organization of the top layers in a core similar to TI.

Red organic matter underwent decarbonation with $1 \mathrm{~N} \mathrm{HCl}$, rinsing with demineralized water, and then oven-drying at $60{ }^{\circ} \mathrm{C}$. The dry sample was combusted under pure $\mathrm{O}_{2}$ flow. $\mathrm{O}_{2}$ acts as both oxidizing agent and carrier gas. The evolved gas was purified on line by flowing into $\mathrm{AgNO}_{3}$ (to remove the $\mathrm{Cl}$, we may have introduced during chemical treatment) and into a $\mathrm{CrO}_{3} / \mathrm{H}_{2} \mathrm{SO}_{4}$ solution (to oxidize nitrogen and sulfur compounds to the $\mathrm{NO}_{3}{ }^{-}$and $\mathrm{SO}_{4}{ }^{2-}$ forms remaining in the solution). The water was then trapped in a $-80{ }^{\circ} \mathrm{C}$ ethanol trap (frozen by liquid nitrogen) and $\mathrm{CO}_{2}$ was captured from the $\mathrm{O}_{2}$ carrier gas in a temperature-regulated trap that smartly allows to keep the temper- 


\section{$J$ Trichet et al.}

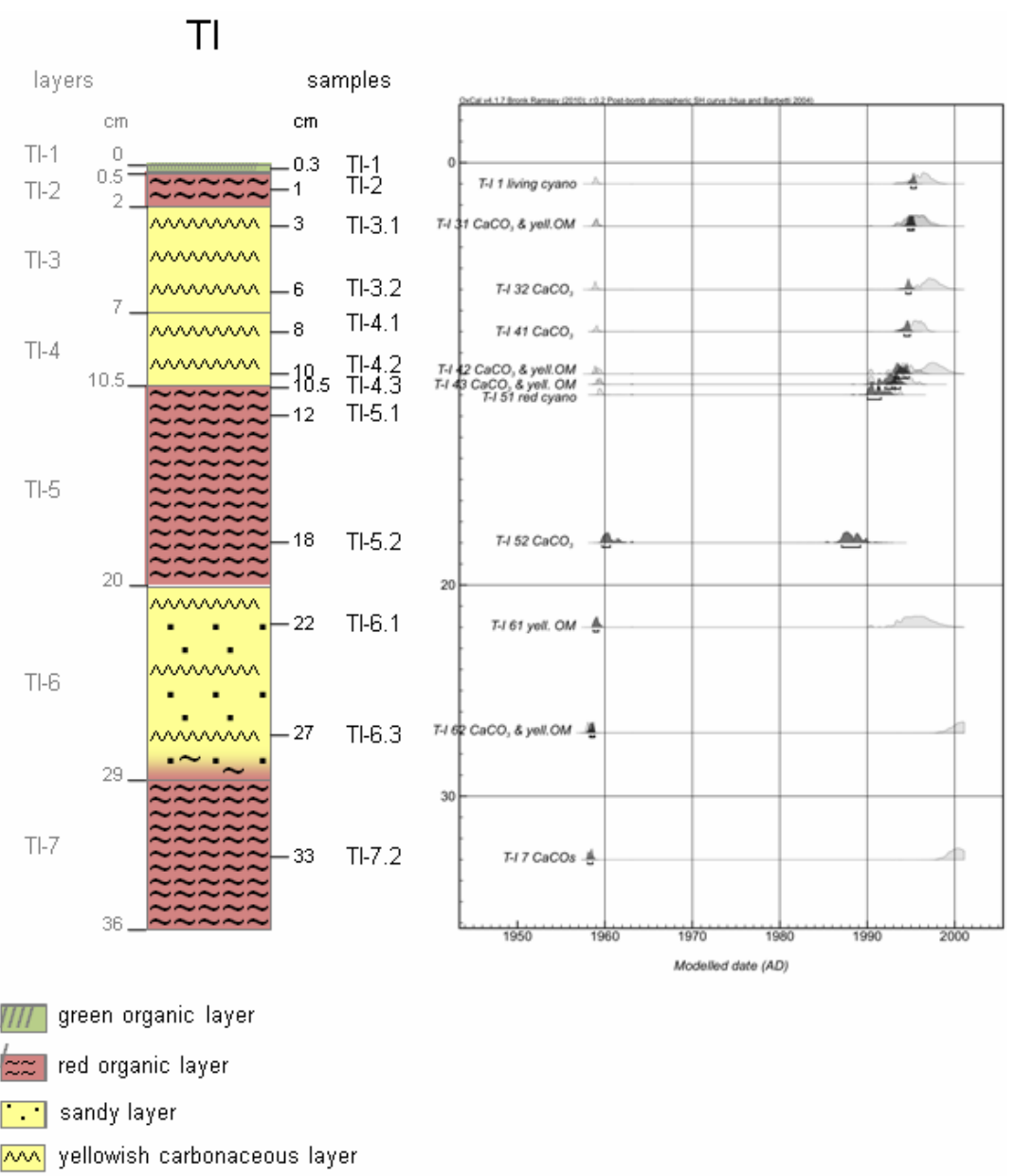

Figure 2 TI sedimentological description and ${ }^{14} \mathrm{C}$ results. The ${ }^{14} \mathrm{C}$ chronological model takes into account the probability of calibrated ages (prior: light gray) according to CALIB (Reimer et al. 2004a) on the Southern Hemisphere atmospheric $\mathrm{CO}_{2}{ }^{14} \mathrm{C}$ record (Hua and Barbetti 2004) and the probability of modeled ages (posterior: black) according to OxCal based on a Bayesian modeling that includes both calibrated age probability distributions and stratigraphical order (Bronk Ramsey 2008).

ature at $-167^{\circ} \mathrm{C}$, leading to $\mathrm{CO}_{2}$ trapping without trapping $\mathrm{O}_{2}$. The resulting $\mathrm{CO}_{2}$ was then cryogenically carried to a purification line where all the potential remaining $\mathrm{O}_{2}$ and sulfur oxide gas were trapped on $\mathrm{Cu}$, kept at $450{ }^{\circ} \mathrm{C}$, as $\mathrm{CuO}, \mathrm{CuO}_{2}$, and $\mathrm{CuS}$. The evolved $\mathrm{CO}_{2}$ was then $100 \%$ pure $\mathrm{CO}_{2}$.

Yellowish organic matter included in the carbonate layers was also extracted from carbonaceous sediment by decarbonation. To avoid any organic matter hydrolysis in such an organic-poor sediment, soft decarbonation was performed: the sediment was covered with water to which $1 \mathrm{~N} \mathrm{HCl}$ was progressively added, the supernatant was removed, and the process repeated until total decarbonation. Combustion and purification of $\mathrm{CO}_{2}$ followed the process described above.

Mineral carbon of carbonate minerals was also extracted, as $\mathrm{CO}_{2}$ gas to be dated. The carbonaceous sediments were leached by pure $\mathrm{H}_{3} \mathrm{PO}_{4}$ in a vacuum line, without any previous chemical treatment. Transiting through two $-80{ }^{\circ} \mathrm{C}$ traps dried the evolving $\mathrm{CO}_{2}$. 
${ }^{14} \mathrm{C}$ Dating of Recent Intertidal Microbial Mats on Atoll Rims
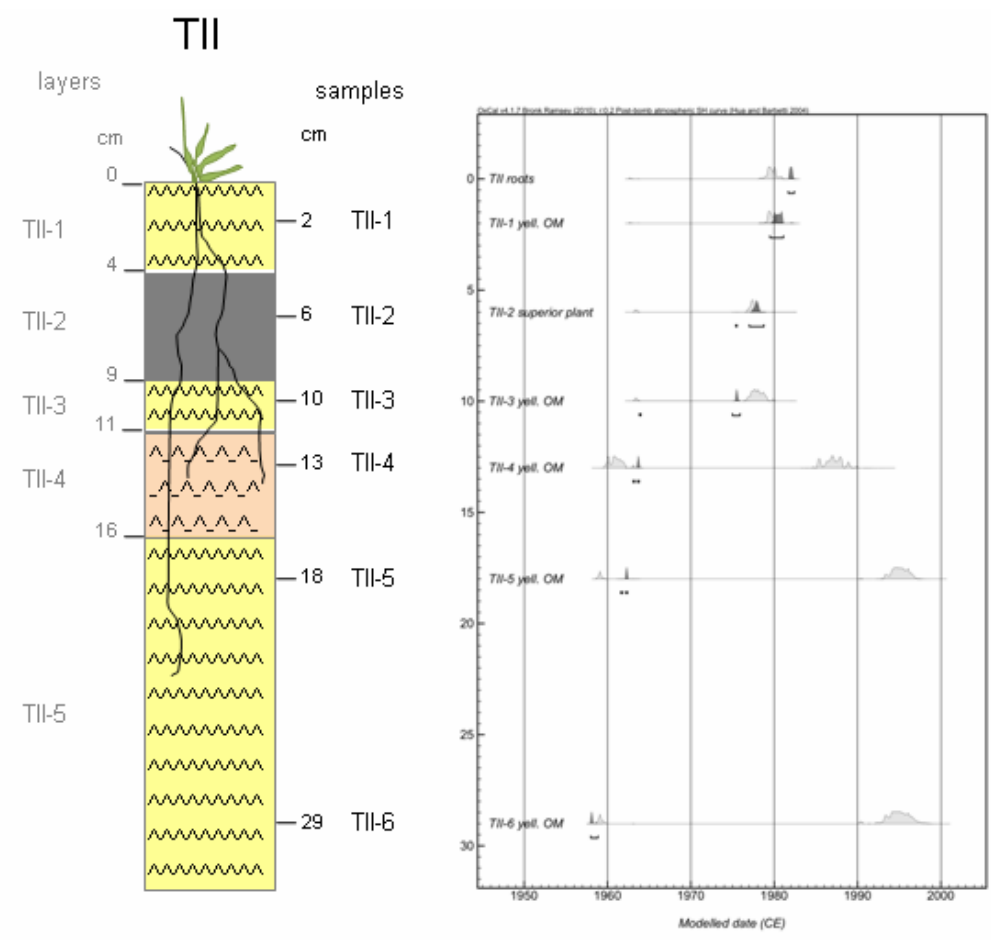

superior plant

A_A dark yellow carbonaceous layer

M yellowish carbonaceous layer

Figure 3 TII sedimentological description and ${ }^{14} \mathrm{C}$ results. The ${ }^{14} \mathrm{C}$ chronological model takes into account the probability of calibrated ages (prior: light gray) according to CALIB (Reimer et al. 2004a) on the Southern Hemisphere atmospheric $\mathrm{CO}_{2}{ }^{14} \mathrm{C}$ record (Hua and Barbetti 2004) and the probability of modeled ages (posterior: black) according to OxCal based on a Bayesian modeling that includes both calibrated age probability distributions and stratigraphical order (Bronk Ramsey 2008).

Pure $\mathrm{CO}_{2}$ gas fractions were later introduced into a custom-made $\mathrm{CO}_{2}$ gas proportional counter in which their activity was determined by comparison with that of 2 standards $\left({ }^{14} \mathrm{C}\right.$-free $\mathrm{CO}_{2}$ and $\mathrm{CO}_{2}$ derived from Oxalic Acid I). ${ }^{14} \mathrm{C}$ activity is presented in pMC (\%), $\Delta^{14} \mathrm{C}(\%)$, and $\mathrm{F}^{14} \mathrm{C}$ as recommended by Stuiver and Polach (1977) and Reimer et al. (2004b) (see Appendix for formulae).

\section{RESULTS}

Results are shown in Tables 1 and 2 for Tetiaroa I and II, respectively. All samples but 1 show modern ${ }^{14} \mathrm{C}$ activity leading, from a cursory glance at the sections, to an age falling within the ${ }^{14} \mathrm{C}$ bomb peak, i.e. from 1955 to the present. The dead cyanobacteria of the TI-5.2 sample show a more depleted corrected $\Delta^{14} \mathrm{C}$ value than the rest of the series: $\Delta^{14} \mathrm{C}=-58 \pm 4 \%$. Likewise, organic carbon from the yellowish TI-3.2 and TI-4.1 samples seem to be outlier values: too-high and too-low ${ }^{14} \mathrm{C}$ activities by comparison with adjacent samples, respectively. 


\section{$J$ Trichet et al.}

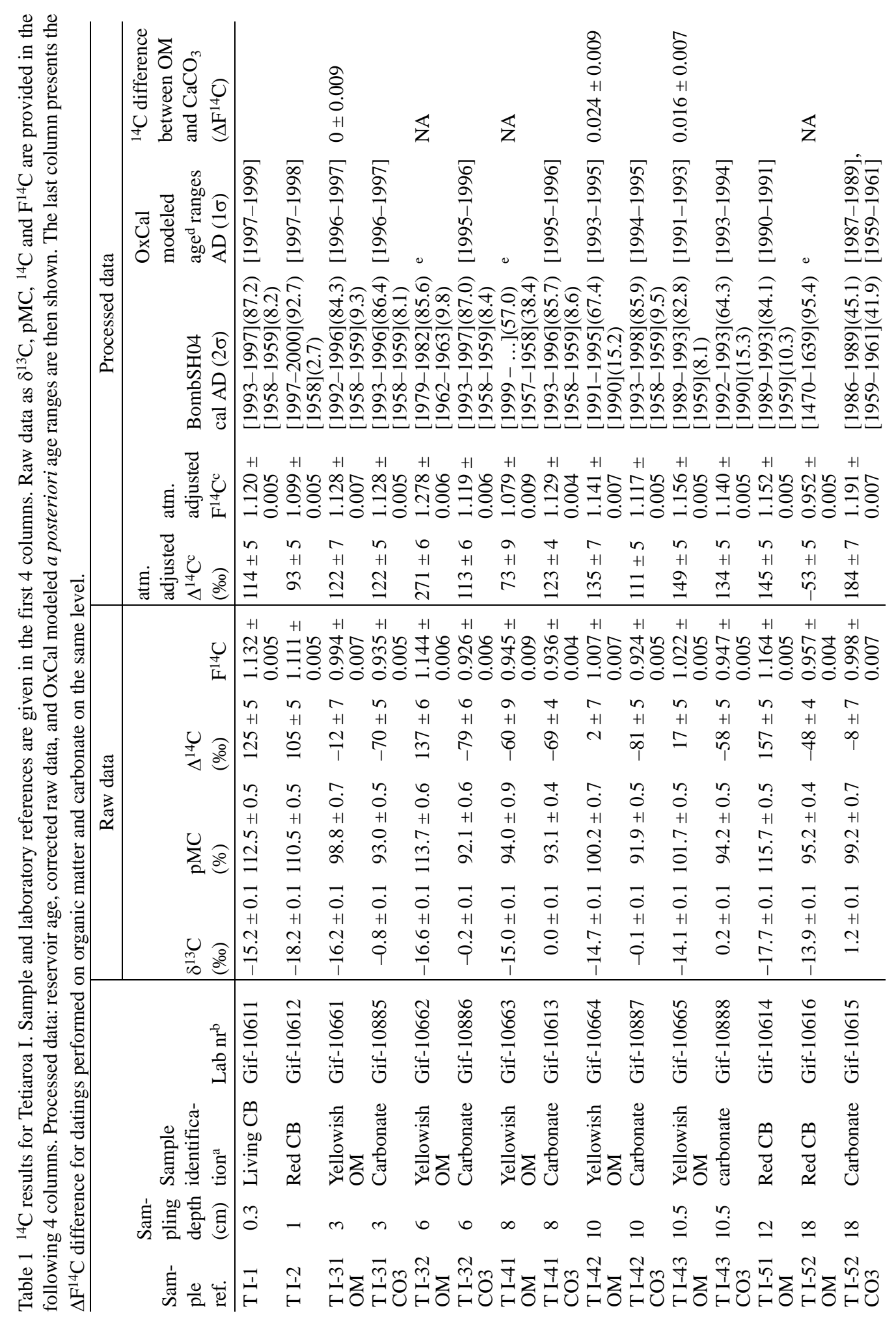




\section{${ }^{14} \mathrm{C}$ Dating of Recent Intertidal Microbial Mats on Atoll Rims}
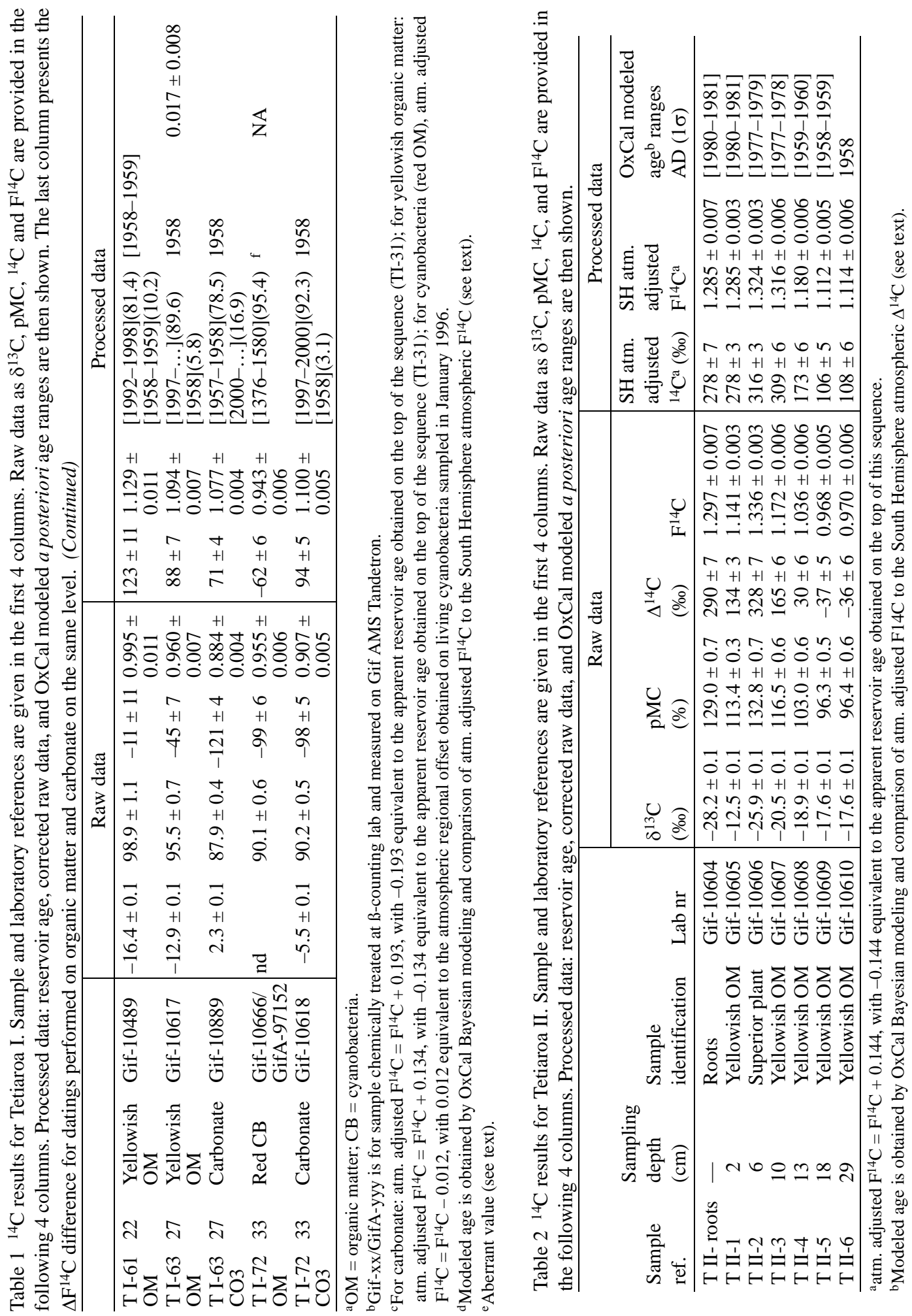


\section{J Trichet et al.}

\section{Reservoir Effect Corrections}

Carbonaceous sediment components contain carbon that derives from different sources: atmospheric $\mathrm{CO}_{2}$, dissolved marine carbon, and underground water dissolved carbon that is either incorporated through photosynthetic carbon fixation forming organic compounds and hence organic matter, or biologically or physically precipitated to form carbonate. Marine and underground water derived carbon show depleted ${ }^{14} \mathrm{C}$ activity due to mixing with old deeper water masses and ${ }^{14} \mathrm{C}$ disintegration in a reservoir not subjected to atmospheric influence, respectively. In such a configuration, every ${ }^{14} \mathrm{C}$ activity has to be corrected by the so-called "reservoir age" to reflect atmospheric ${ }^{14} \mathrm{C}$ activity at the time of integration of the carbon atoms within organic matter or carbonate minerals. Three different components were ${ }^{14} \mathrm{C}$ investigated and considered separately: red organic matter; carbonate; and yellowish organic matter embedded in carbonate layers.

Red organic matter. Tetiaroa I was sampled in January 1996 and was overlaid by living cyanobacteria (green alive and red after death) and bacteria. It is thus reasonable to associate the activity in the upper part of the core to the mid-1995 atmospheric activity, i.e. $\mathrm{F}^{14} \mathrm{C}=1.120$. The measured $\mathrm{F}^{14} \mathrm{C}$ of the living bacteria is $1.132 \pm 0.005$. The low extent of the shift between regional atmosphere and cyanobacteria ${ }^{14} \mathrm{C}$ activity argues for the predominant use of atmospheric $\mathrm{CO}_{2}$ as the carbon source for the red organic matter and the shift of $\sim 0.012$ can be attributed to a local geographical effect. This $\Delta \mathrm{F}^{14} \mathrm{C}=0.012$ regional atmospheric offset was applied to all the organic matter samples from red layers (TI-2, TI-5.1, TI-5.2, and TI-7.2).

Yellowish organic matter. The layer just below this upper red level (TI-3.1) can reasonably be considered to have been deposited the year before: i.e. 1994. The 1994 atmospheric $\mathrm{F}^{14} \mathrm{C}$ was 1.128 , with a measured ${ }^{14} \mathrm{C}$ activity of $0.994 \pm 0.007$ for the organic carbon in the carbonate layers (yellowish organic matter); the reservoir effect to be applied is $\Delta \mathrm{F}^{14} \mathrm{C}_{/ \text {South Hem }}=0.134$ by comparison with South Hemisphere atmospheric ${ }^{14} \mathrm{C}$ activity, or $\Delta \mathrm{F}^{14} \mathrm{C}_{\text {local }}=-0.146$ by comparison with local atmospheric ${ }^{14} \mathrm{C}$ activity. These values were applied to the yellowish samples: TI-3.1; TI-3.2; TI-4.1; TI4.2; TI-4.3; TI-6.1; TI-6.3.

Carbonate. We assume that carbonate ${ }^{14} \mathrm{C}$ activity mimics contemporaneous atmospheric ${ }^{14} \mathrm{C}$ activity. This assumption is based on previous studies arguing that carbonate carbon derives partly from the surrounding organic matter through biologically influenced authigenic precipitation synchronously with or shortly after organic deposition (Van Lith et al. 2003; Dupraz et al. 2009). As expected for any anaerobic degradation of organic matter, degradation leads to ${ }^{13} \mathrm{C}$-enriched $\mathrm{CO}_{2}$ and ${ }^{13} \mathrm{C}$-depleted $\mathrm{CH}_{4}$ (if any) and ${ }^{13} \mathrm{C}$-depleted residual organic matter (Irwin et al. 1977). This fact agrees with the enriched ${ }^{13} \mathrm{C}$ signature recorded for carbonate in $\mathrm{TI}$, which is increasingly enriched with depth (Table 1).

The 1994 atmospheric $\mathrm{F}^{14} \mathrm{C}$ was 1.128 , with a measured ${ }^{14} \mathrm{C}$ activity of $0.935 \pm 0.005$ for the carbonate. Thus, the reservoir effect to be applied is $\Delta \mathrm{F}^{14} \mathrm{C}_{/ \text {South Hem }}=-0.193$ by comparison with South Hemisphere atmospheric ${ }^{14} \mathrm{C}$ activity, or $\Delta \mathrm{F}^{14} \mathrm{C}_{\text {local }}=-0.205$ by comparison with local atmospheric ${ }^{14} \mathrm{C}$ activity. The similar reservoir effect obtained for the yellowish organic matter and for carbonate implies that an exogenous ${ }^{14} \mathrm{C}$-depleted source (erosion of surrounding carbonate catchment) for carbonate is unlikely. Our assumption is further supported by the coherence of the ages obtained on the lower layers to which the estimated reservoir effects were applied. On this basis, we calculated the atmospheric equivalent $\mathrm{F}^{14} \mathrm{C}$ of all the measured samples. The adjusted ${ }^{14} \mathrm{C}$ data are shown in Table 1. 
${ }^{14} \mathrm{C}$ Dating of Recent Intertidal Microbial Mats on Atoll Rims

Tetiaroa II contained higher plant roots embedded in the TII-1 layer. Higher plant roots are in equilibrium with the atmosphere from which carbon is extracted by photosynthesis; the root ${ }^{14} \mathrm{C}$ therefore equals the contemporaneous atmospheric ${ }^{14} \mathrm{C}$. By comparing the ${ }^{14} \mathrm{C}$ activity of TII- 1 yellowish organic matter to the root ${ }^{14} \mathrm{C}$ activity, the reservoir effect to be applied on all Tetiaroa II yellowish organic samples can be defined. Root $\mathrm{F}^{14} \mathrm{C}$ is 1.297 and the TII- 1 yellowish organic matter $\mathrm{F}^{14} \mathrm{C}$ is 1.141. The reservoir effect of Tetiaroa II yellowish organic samples is therefore $\Delta \mathrm{F}^{14} \mathrm{C}_{\text {/local }}=-0.156$ by comparison with local atmospheric ${ }^{14} \mathrm{C}$ activity, and $\Delta \mathrm{F}^{14} \mathrm{C}_{/ \text {South Hem }}=-0.144$ by comparison with South Hemisphere atmospheric ${ }^{14} \mathrm{C}$ activity if the same local atmospheric offset as in TI is used. Equivalent atmospheric $\mathrm{F}^{14} \mathrm{C}$ values are shown in Table 2. Note the similarity in reservoir effect for yellowish organic matter in core $\mathrm{TI}\left(\Delta \mathrm{F}^{14} \mathrm{C}_{/ \text {South Hem }}=-0.134\right)$ and that in core $\mathrm{TII}\left(\Delta \mathrm{F}^{14} \mathrm{C}_{/ \text {South Hem }}=\right.$ -0.144 ), which supports our assumptions of the deposition years of the TI upper layers (TI-1 and TI3.1 attributed to 1995 and 1994, respectively).

\section{Chronological Framework}

To establish the chronology, equivalent atmospheric activity was converted into calendar age by positioning the adjusted $\mathrm{F}^{14} \mathrm{C}$ on the bomb peak as recorded in the Southern Hemisphere (Hua and Barbetti 2004). Several possibilities are offered for each sample within the range of measurement uncertainty, on both sides of the peak but also considering small fluctuations along the peak (see Figure 4 for TII). The choice was made according to the stratigraphy, an upper layer being considered younger than a lower one. We used OxCal v 4.1 software (Bronk Ramsey 2009) to model the most likely interval (Figures 2, 3, and 4 and Tables 1 and 2, last column). We selected the PSequence option. The resulting $\mathrm{A}_{\text {overall }}$ value was $27.3 \%$ for TI and of $62.3 \%$ for TII. The low value obtained for TI might be due to the high amount of dates that reduce the freedom degree and to their high ${ }^{14} \mathrm{C}$ activity that returns to equally probable dating: one prior and one after the bomb peak. With a lower number of dates, $\mathrm{A}_{\text {overall }}$ passed the threshold of $60 \%$ for TII.

Figures 2 and 3 show comparable results for the ages of cores TI and TII, respectively. The results in both cores cluster around the peak of maximum activity with a lack of sedimentation within the time interval of [1958-1959] (sample TI-6.1) to [1990-1991] (sample TI-5.2) in core TI and in the interval of [1959-1960] (sample TII-4) to [1977-1978] (sample TII-3) in core TII. They both show an alternation of sedimentation and erosion phases.

Whereas the bottom parts of the 2 cores are approximately contemporaneous, deposited in 19581959, their facies are different, ranging from a well-defined kopara layer in the core of the pond TI (layer TI-7) to a mixture of kopara and calcareous sand on the border of the pond (layers TII-6 and TII-5). The following period shows a highly different sedimentological regime in the 2 sections: the pond TI is the seat of a carbonaceous sand deposit, in 1959, while, $20 \mathrm{~m}$ apart, in the TII site, no mechanical process is recorded, leading to a normal kopara succession, up to year 1960 (layer TII4). From that year, no microbial sediment is registered in either part of the pond, up to 1987 in core TI (sample TI-5.2) and up to 1976-1977 in core TII (sample TII-3). This hiatus is due to probable alternations of sedimentation and erosion processes. Sedimentation takes over again with the deposition of a layer of higher plant remains in site TII (sample TII-2, dated 1978), overlying the yellowish carbonaceous layer (sample TII-3, dated 1977), followed by a second, final kopara invasion dated 1979. In TI, sedimentation started again with a second red organic layer (TI-5.2, dated 1987 up to TI-5.1, dated 1991) up to 1991, followed by another shorter hiatus between TI-5.1 and TI-4.3 that lasted 1 to 3 yr before a further alternation of red and yellowish carbonaceous layers from 1993 (sample TI-4.3) to the date of sampling (January 1996). Figure 5 summarizes the correlations made possible from ${ }^{14} \mathrm{C}$ dating the sedimentary deposits of the 2 sites. 


\section{$J$ Trichet et al.}

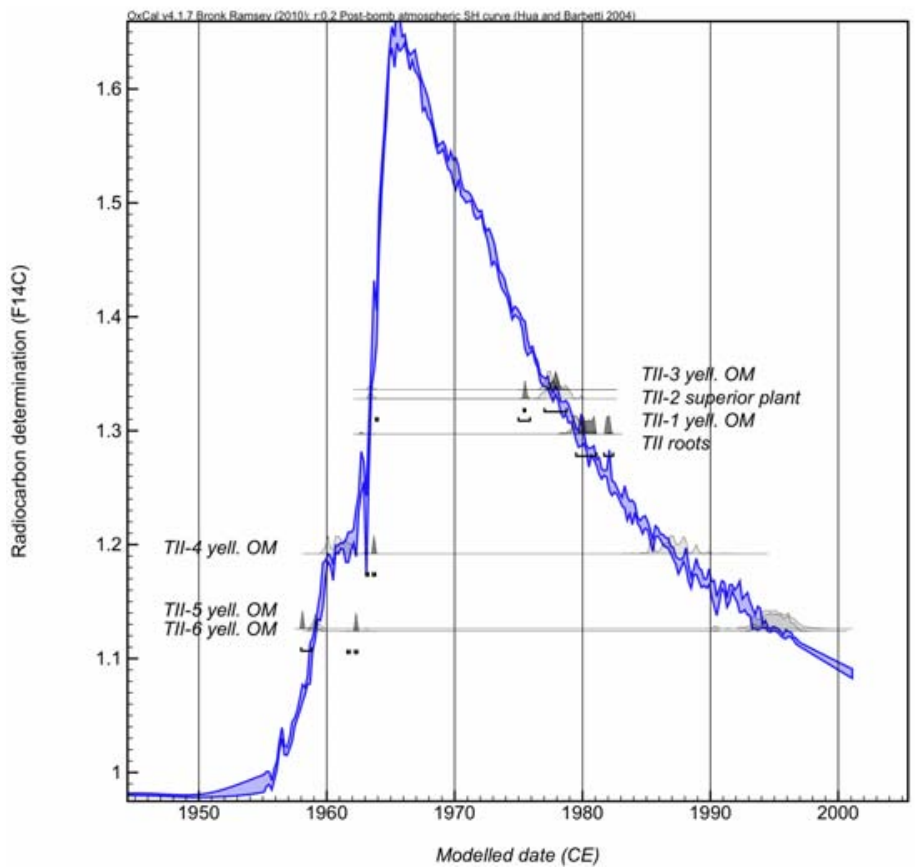

Figure 4 TII chronological age model on the peak bomb record (Hua and Barbetti 2004). ${ }^{14} \mathrm{C}$ ages take into account the probability of calibrated ages (prior: light gray) according to CALIB (Reimer et al. 2004a) on the Southern Hemisphere atmospheric $\mathrm{CO}_{2}{ }^{14} \mathrm{C}$ record (Hua and Barbetti 2004) and the probability of modeled ages (posterior: black) according to OxCal based on a Bayesian modeling that includes both calibrated age probability distributions and stratigraphical order (Bronk Ramsey 2008). The blue curve represents the bomb peak record (Hua and Barbetti 2004).

The resulting accumulation rates argue for a similar behavior in the 2 cores, i.e. a much higher sedimentation rate before the 1960s-1970s hiatus than after: 110 and $22 \mathrm{~mm} / \mathrm{yr}$, respectively, for TI and 107 and $32 \mathrm{~mm} / \mathrm{yr}$, respectively for TII.

\section{DISCUSSION}

Several outstanding features are outlined herein. This study provides new evidence for the authigenic character of the carbonate grains within the organic matter hosting them and for the inheritance of their carbon fraction from oxidation of the organic matter carbon atom pool. Indeed, to evaluate the reservoir effects for the carbon of carbonate and yellowish organic matter, we postulated for the top core that carbonate and organic matter had the same ${ }^{14} \mathrm{C}$ signature and assigned this layer to the year 1994. The 2 resulting reservoir effects are very close, differing by only 0.06 in $\mathrm{F}^{14} \mathrm{C}$, which argues in favor of the same origin for the carbon in both cases. This corroborates the idea that most if not all of the carbon from carbonate derives from organic matter mineralization rather than from surrounding freshwater or ocean dissolved inorganic carbon. Applied on subsequent layers (samples TI-4.2, TI-4.3, and TI-6.3), estimated reservoir effects provide an equivalent age for the carbonate fraction and the organic matter fraction from the same sample, thus validating our initial assumption. This result does not mean that carbonate precipitation and organic matter deposition are synchronous. Nevertheless, as carbonate is present in the layer TI-3 dated on organic matter at 1995 or younger, and as sampling was performed in January 1996, we can assert that carbonate precipitation occurred less than 1 or 2 yr after kopara deposition. 
${ }^{14} \mathrm{C}$ Dating of Recent Intertidal Microbial Mats on Atoll Rims

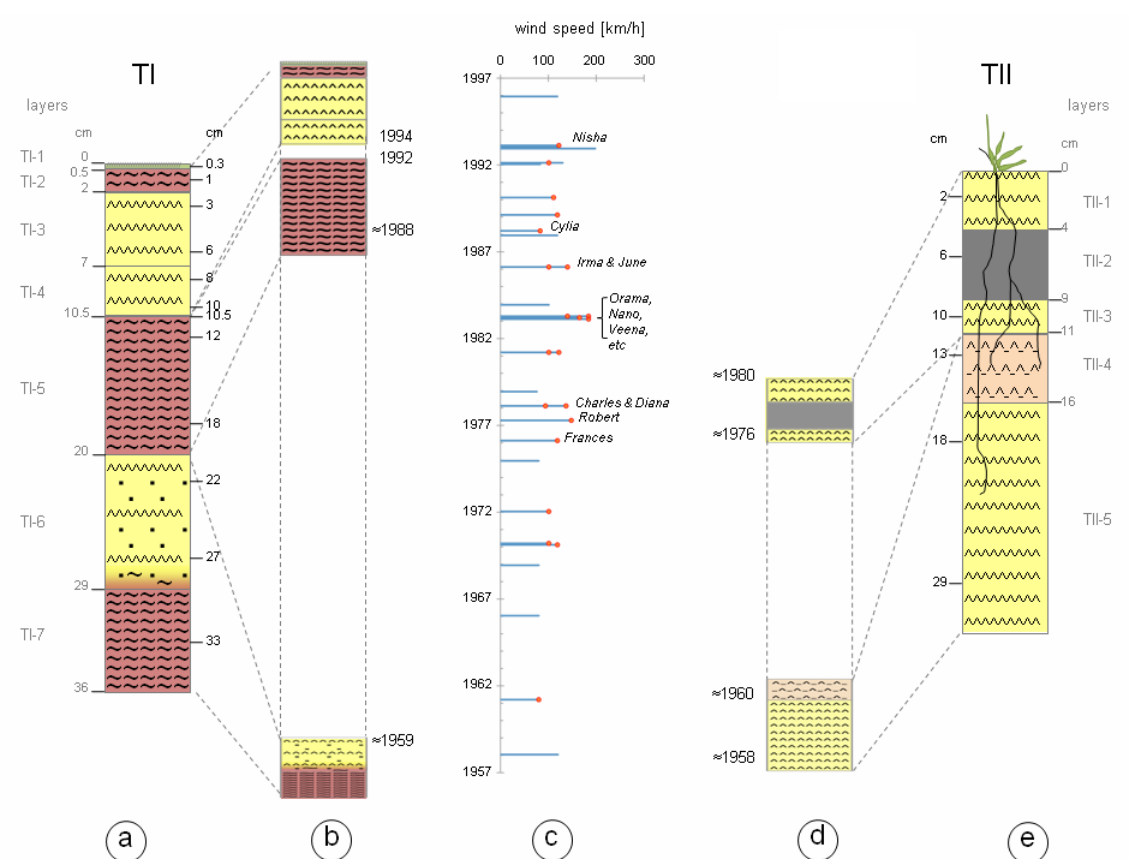

Figure 5 TI and TII records plotted versus cyclones and tropical storms recorded in French Polynesia (Larrue and Chiron 2010). On both sides, (a) shows simplified descriptions of TI and TII versus depth (the legend is the same as in Figures 2 and 3, respectively). (b) and (d) are facies descriptions of TI and TII versus time (the facies are the same as in Figures 2 and 3, respectively, and the timescale is the same as in panel c). Panel (c) records the wind speeds of tropical storms and cyclones (Larrue and Chiron 2010). Red dots highlight December to April events.

The sedimentological evidence shows a sharp hiatus with erosional or non-depositional processes that can result in the lack of entire layers, between TI-6.1 and TI-5.2, TI-5.1 and TI-4.3, and TII-4 and TII-3 samples. It is noteworthy that the hiatuses are not synchronous in the 2 cores. A comparison between the cores and with the record of cyclones and tropical storms over French Polynesia (Larrue and Chiron 2010) reveals a regional sedimentation pattern along the last half of the 20th century that takes meteorological forcing into account (Figure 5). Since the path of spring cyclones and tropical storms lies over French Polynesia (Larrue and Chiron 2010), we mostly focused on events that occurred from February to April (highlighted with a red dot in Figure 5).

On TI, all the sediment deposited between 1959 and 1987 was removed during strong climatic events that occurred during this period, in particular during spring storms and cyclones that hit Tetiaroa atoll (Larrue and Chiron 2010). On TII, the important erosional phase began later, since the proper kopara layer (layer TII-4) acted as a protection against erosion until later than 1961, protecting the sediment accumulation during the 1961 event. However, since environmental conditions were no longer favorable to a proper kopara (at 1962), a similar deposit-erosion period occurred on the bank of the pond as in the middle and lasted until the mid-1970s when sand dune movements resulted in the emersion of T-II and the deposition of a yellowish facies (layer TII-3) followed by blackish "terrestrial" sediments (layer TII-2) that protected the underlying sediments. This emersion phase occurred during the successive Frances and Robert cyclones (1976 and early 1977) and lasted until mid- to late 1977 when environmental conditions favorable to proper kopara development were restored. The reddish layer (layer TII-1) then protected the sediment accumulation during the 


\section{$J$ Trichet et al.}

Charles and Diana events in 1978. At TI, the return to conditions favorable to a proper kopara accumulation occurred much later, in 1987, 4 yr after the ruinous year 1983, which experienced 5 severe climatic events, including 3 spring class 3 cyclones that had a devastating impact on the whole atoll coast, including TI and TII.

From 1987 on, TI sediment accumulation was covered by a proper kopara (layer TI-5) and was protected against 4 spring climatic tropical storms until the 1992 event. Unfortunately, conditions favorable to proper kopara development ceased in 1992, leading to calcareous sedimentation (layer TI-4) that was unable to resist the Nisha storm in 1993. The following calcareous sedimentation is still visible as no climatic disasters occurred between 1993 and early 1995, the date when kopara conditions were restored and that lasted until the sampling date.

These observations and datings show that the red layers are the most resistant to erosional processes. This results from the acquisition of a resistant mechanical structure due to the intertwining of polysaccharidic-proteinic fibers liberated by the dispersion of the fibrous constituents of the sheaths of the dying cyanobacteria, at the bottom of the green layer (Défarge et al. 1994b, 1996).

Both age models evidence a similar drastic decrease in the accumulation rate following a period with intense and dramatic climatic events. An accumulation rate of $\sim 110 \mathrm{~mm} / \mathrm{yr}$ was recorded before the 1960s/1970s tropical storms and cyclones, whereas $\sim 25 \mathrm{~mm} / \mathrm{yr}$ is the present accumulation rate in both parts of the pond. This shows the vulnerability of this ecosystem and its weak resilience to climatic impact. Whereas kopara accumulation could have been considered a renewable resource for cosmetic or agronomy industries in the 1950s, it appears, at least in the pond studied here, as a deposit that accumulates much more slowly today and that can therefore be used only sparingly for industrial purposes.

\section{CONCLUSION}

A combination of ${ }^{14} \mathrm{C}$ activity measurement on both organic and mineral constituents, reservoir effect estimation, and comparison with the Southern Hemisphere atmospheric bomb-peak ${ }^{14} \mathrm{C}$ record allowed us to establish that microbial mat accumulation is not continuous and consists of sets of multicolored layers. As a whole, these dates show that the accumulation rate can reach $10 \mathrm{~cm} / \mathrm{yr}$ during periods favorable to mat development (the late 1950s in our study) but is 5-fold less today. The preservation of kopara successions is highly dependent on external parameters, among which climate events are of major importance. The lack of layers with ages intermediate between the measured ones coincides with periods of heavy storms, hurricanes, and cyclones that hit Polynesia between 1958 and 1996. These events, however, kept the deepest layers of this fragile deposit in place. Furthermore, this study clearly demonstrates that the carbonate and organic matter of the same level show similar ${ }^{14} \mathrm{C}$ activity. This argues in favor of the same origin for the carbon of the 2 components and thus an in situ production of carbonate, precipitating from organic matter mineralization. Such global results are interesting for reconstructing the sedimentological and petrographical history of microbially derived sedimentary deposits and, presently, for the use of organic, potentially fast-growing, and renewable resources.

\section{ACKNOWLEDGMENTS}

Thanks are due to S Martin, C Noury, and M Jaudon for the preparation and the measurement of carbon isotope ratios. We would like to express our sincerest thanks to the 2 anonymous reviewers for their highly constructive comments and suggestions. This is an LSCE-4545 contribution. 


\section{${ }^{14} \mathrm{C}$ Dating of Recent Intertidal Microbial Mats on Atoll Rims}

\section{REFERENCES}

Abed RMM, Kohls K, de Beer D. 2007. Effect of salinity changes on the bacterial diversity, photosynthesis and oxygen consumption of cyanobacterial mats from an intertidal flat of the Arabian Gulf. Environmental Microbiology 9(6):1384-92.

Arp G, Helms G, Karlinska K, Schumann G, Reimer A, Reitner J, Trichet J. 2012. Photosynthesis versus exopolymer degradation in the formation of microbialites on the atoll of Kiritimati, Republic of Kiribati, central Pacific. Geomicrobiology Journal 29(1):2965.

Bronk Ramsey C. 2008. Deposition models for chronological records. Quaternary Science Reviews 27(1-2): 42-60.

Bronk Ramsey C. 2009. Bayesian analysis of radiocarbon dates. Radiocarbon 51(1):337-60.

Camoin G, Gautret P, Montaggioni L, Cabioch G. 1999. Nature and environmental significance of microbialites in Quaternary reefs: the Tahiti paradox. Sedimentary Geology 126(1-4):271-304.

Camoin G, Cabioch G, Eisenhauer A, Braga JC, Hamelin B, Lericolais G. 2006. Environmental significance of microbialites in reef environments during the last deglaciation. Sedimentary Geology 185(3-4):277-95.

Decho AW, Visscher PT, Reid RP. 2005. Production and cycling of natural microbial exopolymers (EPS) within a marine stromatolite. Palaeogeography, Palaeoclimatology, Palaeoecology 219(1-2):71-86.

Défarge C, Trichet J, Couté A. 1994a. On the appearance of cyanobacterial calcification in modern stromatolites. Sedimentary Geology 94(1-2):11-9.

Défarge C, Trichet J, Maurin A, Hucher M. 1994b. Kopara in Polynesian atolls: early stages of formation of calcareous stromatolites. Sedimentary Geology 89(12):9-23.

Défarge C, Trichet J, Jaunet AM, Michel R, Tribble J, Sansone F. 1996. Texture of microbial sediments revealed by cryo-scanning electron microscopy. Journal of Sedimentary Research 66(5):935-47.

Dupraz C, Reid RP, Braissant O, Decho AW, Norman RS, Visscher PT. 2009. Processes of carbonate precipitation in modern microbial mats. Earth-Science Reviews 96:141-62.

Franks J, Stolz JF. 2009. Flat laminated microbial mat communities. Earth-Science Reviews 96(3):163-72.

Garcia-Pichel F, Al-Horani FA, Farmer JD, Ludwig R, Wade BD. 2004. Balance between microbial calcification and metazoan bioerosion in modern stromatolitic oncolites. Geobiology 2(1):49-57.

Gischler E, Gibs MA, Oschmann W. 2008. Giant Holocene freshwater microbialites, Laguna Bacalar, Quintana Roo, Mexico. Sedimentology 55(5):1293-309.

Heindel K, Gibs MA, Peckmann J, Kuhnert H, Westphal H. 2010. Formation of deglacial microbialites in coral reefs off Tahiti (IODP310) involving sulfate-reducing bacterica. Palaios 25(10):618-25.
Hua Q, Barbetti M. 2004. Review of tropospheric bomb ${ }^{14} \mathrm{C}$ data for carbon cycle modeling and age calibration purposes. Radiocarbon 46(3):1273-98.

Irwin H, Curtis C, Coleman M. 1977. Isotopic evidence for source of diagenetic carbonates formed during burial or organic-rich sediments. Nature 269(5625): 209-12.

Larrue S, Chiron T. 2010. Les îles de Polynésie française face à l'aléa cyclonique. Vertigo 10(3): http://vertigo.revues.org/10558.

Mao Che L, Andréfouët S, Bothorel V, Guezennec M, Rougeaux H, Guezennec J, Deslandes E, Trichet J, Matheron R, Le Campion T, Payri C, Caumette P. 2001. Physical, chemical and microbiological characteristics of microbial mats (kopara) in the South Pacific atolls of French Polynesia. Canadian Journal of Microbiology 47(11):994-1012.

Reid RP, James NP, Macintyre IG, Dupraz CP, Burne RV. 2003. Shark Bay stromatolites: microfabrics and reinterpretation of origins. Facies 49(1):299-324.

Reid RP, Lopes Gaspar AP, Bowlin EM, Custals L, Andres MS. 2011. Microbialites and sediments: a 2-year record of burial and exposure of stromatolites and thrombolites at Highborne Cay Bahamas. In: Tewari VC, Seckbach J, editors. Stromatolites: Interaction of Microbes with Sediments. Dordrecht: Springer. p 40725.

Reimer PJ, Baillie MGL, Bard E, Bayliss A, Beck WJ, Bertrand C, Blackwell PG, Buck CE, Burr GS, Cutler KB, Damon PE, Edwards RL, Fairbanks RG, Friedrich M, Guilderson TP, Hughen KA, Kromer B, McCormac FG, Manning S, Bronk Ramsey C, Reimer RW, Remmele S, Southon JR, Stuiver M, Talamo S, Taylor FW, van der Plicht J, Weyhenmeyer CE. 2004a. IntCal04 terrestrial radiocarbon age calibration, 0-26 cal kyr BP. Radiocarbon 46(3):1029-58.

Reimer PJ, Brown TA, Reimer RW. 2004b. Discussion: reporting and calibration of post-bomb ${ }^{14} \mathrm{C}$ data. $R a$ diocarbon 46(3):1299-304.

Spadafora A, Perri E, McKenzie JA, Vasconcelos C. 2010. Microbial biomineralization processes forming Ca:Mg carbonate stromatolites. Sedimentology 57(1): 27-40.

Sprachta S, Camoin G, Golubic S, Le Campion T. 2001. Microbialites in a modern lagoonal environment: nature and distribution, Tikehau atoll (French Polynesia). Palaeogeography, Palaeoclimatology, Palaeoecology 175(1-4):103-24.

Stuiver M, Polach HA. 1977. Discussion: reporting of ${ }^{14} \mathrm{C}$ data. Radiocarbon 19(3):355-63.

Trichet J, Défarge C, Tribble J, Tribble G, Sansone F. 2001. Christmas Islands lagoonal lakes: models for the deposition of carbonate evaporite-organic laminated sediments. Sedimentary Geology 140(1-2): 177-89.

van Lith Y, Warthmann R, Vasconcelos C, McKenzie JA. 


\section{$J$ Trichet et al.}

2003. Sulphate-reducing bacteria induce low-temperature Ca-dolomite and high Mg-calcite. Geobiology 1(1):71-9.

Westphal H, Heindel K, Brandano M, Peckmann J. 2010.
Genesis of microbialites as contemporaneous framework components of deglacial coral reefs, deglacial of Tahiti (IODP 310). Facies 56(3):337-52.

\section{APPENDIX}

Formulae used to calculate $\mathrm{F}^{14} \mathrm{C}$, pMC, and $\Delta^{14} \mathrm{C}$

According Stuiver and Polach (1977) and later to Reimer et al. (2004):

$$
\mathrm{F}^{14} \mathrm{C}=\frac{\mathrm{A}_{\mathrm{SN}}}{\mathrm{A}_{\mathrm{ON}}}
$$

where $A_{S N}$ is the measured sample activity after normalizing to $-25 \%$ for $\delta^{13} \mathrm{C}$, and $A_{\mathrm{ON}}$ is $95 \%$ of the measured oxalic acid activity after correction for ${ }^{13} \mathrm{C}$ fractionation.

$\Delta^{14} \mathrm{C}$ is defined by Stuiver and Polach (1977) as:

$$
\Delta^{14} \mathrm{C}=\left[\frac{\mathrm{A}_{\mathrm{SN}}}{\mathrm{A}_{\mathrm{ON}} \times \exp ((y-1950) / 5730 /(\ln 2))}-1\right] \times 1000
$$

where $y$ is the year of measurement.

From Equations (a) and (b), $\Delta^{14} \mathrm{C}$ becomes

$$
\Delta^{14} \mathrm{C}=\left[\frac{\mathrm{F}^{14} \mathrm{C}}{\exp ((y-1950) / 5730 /(\ln 2))}-1\right] \times 1000
$$

pMC is defined by Stuiver and Polach (1977) as:

$$
\mathrm{pMC}=\frac{\mathrm{A}_{\mathrm{SN}}}{\mathrm{A}_{\mathrm{ON}} \times \exp ((y-1950) / 5730 /(\ln 2))} \times 100
$$

from Equations (a) and (d), pMC becomes

$$
\mathrm{pMC}=\frac{\mathrm{F}^{14} \mathrm{C}}{\exp ((y-1950) / 5730 /(\ln 2))} \times 100
$$

